\title{
Evaluation of Antiandrogenic Effects in Castrated Rats Treated with Cassia tora Extract
}

\author{
Samiya Khan ${ }^{1}$, Pratap Chand Mali ${ }^{*}$ \\ ${ }^{1}$ Lecturer, S.S. Jain Subodh Girls College Sanganer, Jaipur, India \\ ${ }^{2}$ Associate Professor, Reproductive Biomedicine and Natural Product Lab, Department of Zoology, University of \\ Rajasthan, Jaipur, India
}

*Address for Correspondence: Dr. Pratap Chand Mali, Associate Professor, Reproductive Biomedicine and Natural Product Lab, Department of Zoology, University of Rajasthan, Jaipur, India

E-mail: malipc zool@yahoo.co.in

Received: 14 Jul 2018/ Revised: 20 Nov 2018/ Accepted: 18 Feb 2019

\begin{abstract}
Background: Practice of artificially altering the rate of growth of human population control has been implemented by limiting the population's birth rate by contraception. The use of Cassia tora plant products for fertility regulation reveals no side effects, therefore to explore the mode of action on androgen of the plant Cassia tora ethanolic extract was administered orally in castrated male wistar rats to develop a cheap, safe, easily administrable, orally effective and reversible fertility regulation for male.

Methods: The control animals (Group A) were treated with sterile distilled water. The animals were subjected to no treatment following their castration for 30 days served as castrated controls (Group B). The seed and stem extracts of the plant, Cassia tora was administered orally to castrated rats (Group C) and testosterone propionate was injected either alone (Group D) or in combination with Cassia tora extract (Group E) to castrated rats. Blood parameters, serum clinical investigations and tissue biochemistry, body and organ weights and level of FSH, LH and testosterone were assessed in all groups.

Results: After the treatment of Cassia tora in castrated rats hormone assay reveals anti-androgenic effect of the drug.

Conclusion: The results revealed that oral administration of Cassia tora affected male fertility by anti-spermatogenic and anti-androgenic action. The decreased weight of accessory sex organs is suggestive of insufficient androgen levels after the extract treatment. Decreased levels of protein, sialic acid and fructose levels support declined production of testosterone level with the Cassia tora extract treatment in rats.
\end{abstract}

Key-words: Androgens, Anti-fertility, Cassia tora, Castration, Male rats

\section{INTRODUCTION}

Birth control is an essential to people of all walks of life, since uncontrolled population caused hazards for human beings. Indian family planning programmes emphasis to female sterilization and various incentives, money, also forced sterilization have been tried in our country and not succeeded. For too long, men have been excluded from the domains of sexual responsibility and reproductive health. It was hoped that the availability

\section{How to cite this article}

Khan S, Mali PC. Evaluation of Antiandrogenic Effects in Castrated Rats Treated with Cassia tora Extract. SSR Inst. Int. J. Life Sci., 2019; 5(2): 2259-2268.

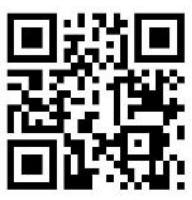

Access this article online https://iijls.com/ and use of acceptable male contraceptive methods could reduce the burden traditionally placed almost exclusively on the female partner ${ }^{[1]}$. Male contraception, or birth control, keeps sperm from coming into contact with an egg to avoid pregnancy. Herbal remedies are widely used for the treatment and prevention of various diseases and often contain highly active pharmacological compounds. Natural contraceptive methods have great potentiality in the control of population in developing countries like India [2]. Although there are currently no systemic methods of contraception for use by men, the development of a male-use equivalent of oral, injectable and implantable female steroid hormone methods of contraception has been the subject of research for the past many years. Medicinal plants are widely used in non-industrialized societies, mainly because they are readily available and cheaper than modern medicines. 
Traditional uses of medicinal plants in its drug discovery efforts solve many problems related to mankind. Plants can be described as a major source of medicines, not only as isolated active principles to be dispensed in standardized dosage form but also as crude drugs for the population ${ }^{[3,4]}$. The ethanolic extract of the plant, Cassia tora shows reversible contraceptive efficacy at different dose levels. Since the use of plant products as fertility regulating agent cause minimal or no side effects as compared to other contraceptive method. The present investigation was planned to evaluate mode of action of activity of $50 \%$ ethanolic extract of the plant Cassia tora.

\section{MATERIALS AND METHODS}

Cassia tora plant- The study was carried out in the Department of Zoology, University of Rajasthan, Jaipur from 2010 August to 2012 December. Cassia tora is belongs to family Fabaceae and also known as Cassia obstusifolia, Foetid cassia, Sickle senna, Wild senna, Charota, Chakvat, Chakvat senna tora etc. The plant Cassia tora is used as a anti-cholestrolemic, antispasmodic, carminative, anti-periodic, anthelminithic, ophthalmic, used in liver tonic, cardiotonic expectorant, leprosy, ringworm, flatulence, colic, dyspepsia, constipation, cough, bronchitis, natural pesticide, and fungicidal activities ${ }^{[5]}$, anti-hepatotoxic ${ }^{[6]}$, anti-allergic ${ }^{[7]}$, antifungal ${ }^{[8]}$, anti-mutagenic, radical scavenging and antimicrobial. Cassia tora has varied bioactivities viz., purgative ${ }^{[9]}$, hypolipidemic ${ }^{[10]}$, larvicidal, anti-oxidant, anti-plasmodial, vermifuge and contraceptive [11,12]. Chemical constituents of the plant Cassia tora were rubrofusarin triglucoside, non-rubrofusarin gentobioside, demethyl-flavasperone, genitobioside, torachrysone gentibioside, torachrysone tetraglucoside, tora chrysone apioglucoside, torachrysone, toralactone aloemodin, rhein, emodin, naphthalene, anthraquinone, methicillinresistant ${ }^{[13,14]}$.

Test material and Animal model- The seed and stem extracts were given to castrated rats (administered orally up to $500 \mathrm{mg} / \mathrm{kg}$ ) did not demonstrate any toxic effect or cause mortality. The extract was prepared according to the WHO protocol CG-04 for the preparation of the alcoholic extract. The resulting mass was dried under vacuum and kept at $-4^{\circ} \mathrm{C}^{[15]}$.

\section{Experimental design and protocol}

Group A: The animals of this group were given vehicle (sterile distilled water) alone orally for 60 days to serves as vehicle controls.

Group B: Animals were subjected to no treatment following their castration for 30 days served as castrated controls.

Group C: Animals were subjected to 30 days castration follow by the administration of Cassia tora at $100 \mathrm{mg} / \mathrm{kg}$. b.wt. for 30 days.

Group D: 30 days castrated animals were injected with testosterone propionate at a dose of 0.01 $\mathrm{mg} / \mathrm{rat} /$ alternate days s.c. for 30 days.

Group E: 30 days castrated animals were receive TP (0.01 mg/alternate day s.c) and Cassia tora extract (100 $\mathrm{mg} / \mathrm{kg}$. b.wt. for 30 days).

Body organ weight- The initial and final body weight of animals were recorded. Epididymis, vas deferens, seminal vesicle, ventral prostate and other vital organs were dissected out for nearest milligram weight.

Tissue biochemistry- Protein ${ }^{[16]}$, sialic acid ${ }^{[17]}$, fructose ${ }^{[18]}$ were estimated in accessory reproductive organs.

Hormone assay- Blood samples were collected for serum separation to estimate $\mathrm{FSH}, \mathrm{LH}$ and testosterone by radioimmunoassay ${ }^{[19]}$.

Histopathological study- Contralateral side of the cauda epididymis, vas deferens, seminal vesicle and ventral prostate were fixed in Bouin's fluid, dehydrated in graded ethanol, cleared in xylene and mount in DPX to observe histopathological changes under the light microscope.

Statistical Analysis- Statistical analysis was based on biological statistics. All the values of body organ weights, biochemical estimations histometery were averaged expressed as Mean \pm Standard error (S.E.). Standard error was calculated. Data were expressed as mean \pm S.E. analyze for statistical significance by using student's " $\mathrm{t}$ " test. The data considered as significant and highly significant at $\mathrm{p} \leq 0.01$ and $\mathrm{p} \leq 0.001$, respectively ${ }^{[20]}$.

Ethical aspects- The study was carried out under the supervision of an ethical committee of the Department 
of Zoology, University of Rajasthan, Jaipur (Vide Letter No. Rs/98/10/7454 dated 19/8/2010) and CPCSEA [21] guidelines were followed to maintain the experimental animals.

\section{RESULTS}

Effect on body and reproductive organ weight- In the present investigation, results of the body weights of Cassia tora treated castrated rats (Group C-E) did not show any significant changes, as compared to control treated vehicle rats (Group A). It has been observed that castration of rats resulted in a significantly decreased $(P \leq 0.001)$ in the weight of reproductive organs like epididymis, vas deferens, seminal vesicle, ventral prostate, as compared to intact control rats (Group A). There were non-significant changes were observed in Cassia tora extract-treated castrated rats (Group C), while significantly increased $(P \leq 0.001)$ in TP administered castrated rats (Group D) and it was increased $(P \leq 0.01)$ in combined treatment of Cassia tora and TP treated rats (Group E) as compared with castrate control rats (Group B) shown in Table 1. There was no significant change was observed in other body organs like kidney, heart, liver and adrenal gland in castrated groups after administration of Cassia tora and TP either alone or in combination with TP.

Changes in blood and Serum profile- Non-significant changes were observed in the levels of blood sugar and urea, RBC, WBC, haemoglobin, haematocrit value, MCV, $\mathrm{MCH}$ and $\mathrm{MCHC}$ after castration in rats following the treatment (Groups C-E) when compared with castrate control rats (Group B). A non-significant change was observed in SGOT and SGPT castrated rats, after the treatment of Cassia tora (Group C) as compared with castrate control rats (Group B). TP administration to castrate rats either alone (Group D) or with Cassia tora (Group E) caused a non-significant alteration in the SGOT and SGPT as compared with castrate control rats (Table 2). Acid phosphatase and Alkaline phosphatase level in castrate rats resulted a significant $(P \leq 0.01)$ increased in rats (Group B), as compared to intact control rats (Group A). Cassia tora when administered orally to castrate rats (Group C) result a non-significant decrease in serum acid and alkaline phosphatase level when compared with castrate control rats (Group B). Administration of TP to castrate rats (Group D) caused a significant elevation $(P \leq 0.01)$ in serum acid and alkaline phosphatase level as compared with castrate control rats (Group B). Combined treatment of Cassia tora and TP to castrate rats (Group E) showed a significant elevation in serum acid and alkaline phosphatase level, when compared with castrate control rats (Group B) (Table 2). In castrated rats (Group B) the LDH level was reduced nonsignificantly, as compared to intact control rats (Group A). The LDH after administration of Cassia tora either alone or in combination with TP to castrated rats (Group C-E), revealed a non-significant alteration in rats, as compared to castrate control rats (Group B) (Table 2).

Changes in tissue biochemistry- The protein and sialic acid contents of castrated rats (Group B) were reduced high significantly $(P \leq 0.001)$ in cauda epididymis, seminal vesicle and ventral prostate as compared to intact control rats (Group A). Cassia tora treatment to castrate rats (Group C) caused a non-significant alteration in protein content and sialic acid contents, as compared to castrate control rats (Group B). While TP administration either alone or in combination with Cassia tora in castrate rats (Group D and Group E) caused a significant increase in protein and sialic acid content of cauda epididymis, in the seminal vesicle and ventral prostate when compared with castrate control rats (Group B) (Table 3). Fructose level of Cassia tora treated castrated rats (Group C) was reduced non significantly in seminal vesicle, Cassia tora and TP treatment to castrate rats (Group E) showed changes significantly in fructose content in seminal vesicle, as compared to castrate control rats (Table 3). Testosterone level nonsignificantly increased in serum after the administration of Cassia tora (Group C) as compared to castrate control rats. When the administration of TP either alone or with Cassia tora to castrate rats (Group D-E), the testosterone level in serum significantly $(P \leq 0.001)$ elevated as compared to castrate control rats (Group B) (Fig. 3). The administration of Cassia tora in castrate rats (Group C), a significant $(P \leq 0.01)$ declined of $F S H$ and $\mathrm{LH}$ level in serum, as compared to castrate control rats. TP administration to castrate rats either alone or with cassia tora (Group D-E) caused a significant depletion ( $\mathrm{P} \leq 0.01$ ) of FSH and $\mathrm{LH}$ level in serum, as compared to castrate control rats (Fig. 4 \& Fig. 5). 
Table 1: Changes in the body and organs weight of castrated male albino rats after the treatment of Testosterone Propionate and Cassia tora

\begin{tabular}{|c|c|c|c|c|c|c|c|}
\hline Treatment & $\begin{array}{l}\text { Initial } \\
\text { b.wt. } \\
\text { (gm.) }\end{array}$ & $\begin{array}{l}\text { Final } \\
\text { b.wt. } \\
\text { (gm.) }\end{array}$ & $\begin{array}{l}\text { Epididymis } \\
\text { mg/100gm } \\
\text { b.wt. }\end{array}$ & $\begin{array}{c}\text { Vas } \\
\text { deferens } \\
\text { mg/100gm } \\
\text { b.wt. }\end{array}$ & $\begin{array}{c}\text { Seminal } \\
\text { vesicle } \\
\text { mg/100gm } \\
\text { b.wt. }\end{array}$ & $\begin{array}{l}\text { Ventral } \\
\text { prostate } \\
\text { mg/100gm } \\
\text { b.wt. }\end{array}$ & $\begin{array}{c}\text { Adrenal gland } \\
\text { mg/100gm } \\
\text { b.wt. }\end{array}$ \\
\hline $\begin{array}{l}\text { Group A } \\
\text { Control }\end{array}$ & $120.00 \pm 2.35$ & $156.50 \pm 1.67$ & $595.26 \pm 10.70$ & $148.26 \pm 2.10$ & $492.42 \pm 3.31$ & $76.50 \pm 1.72$ & $20.71 \pm 0.20$ \\
\hline $\begin{array}{c}\text { Group B } \\
\text { Castration }\end{array}$ & $105.00 \pm 1.67$ & $162.50 \pm 0.83$ & $501.35 \pm 3.06 * *$ & $124.09 \pm 1.49 * *$ & $454.89 \pm 3.37 * *$ & $65.80 \pm 2.09 * *$ & $20.00 \pm 0.28^{n s}$ \\
\hline $\begin{array}{c}\text { Group C } \\
\text { Castration + } \\
\text { Cassia tora } \\
100\end{array}$ & $106.00 \pm 1.63$ & $162.00 \pm 0.82$ & $500.22 \pm 3.44^{\mathrm{ns}}$ & $123.43 \pm 1.90^{\mathrm{ns}}$ & $452.80 \pm 3.00^{\mathrm{ns}}$ & $65.39 \pm 1.55^{\mathrm{ns}}$ & $19.93 \pm 0.22^{\mathrm{ns}}$ \\
\hline $\begin{array}{c}\text { Group D } \\
\text { Castration + } \\
\text { Testosterone } \\
\text { Propionate }\end{array}$ & $104.00 \pm 1.63$ & $162.50 \pm 0.83$ & $512.26 \pm 3.53 *$ & $129.51 \pm 1.33^{*}$ & $468.95 \pm 2.92 * *$ & $71.25 \pm 1.43^{*}$ & $19.50 \pm 0.22^{\mathrm{ns}}$ \\
\hline $\begin{array}{c}\text { Group E } \\
\text { Castration + } \\
\text { Testosterone } \\
\text { Propionate+ } \\
\text { Cassia tora } \\
100 \\
\text { mg/kg.b.wt. }\end{array}$ & $105.00 \pm 1.67$ & $162.50 \pm 0.83$ & $510.25 \pm 2.34 *$ & $129.33 \pm 1.16^{*}$ & $466.54 \pm 4.68 *$ & $70.79 \pm 0.95 *$ & $19.81 \pm 0.18^{\mathrm{ns}}$ \\
\hline
\end{tabular}

Data exposed as Mean $\pm S . E, n s=$ non-significant, ${ }^{*}$ Significant $(P \leq 0.01),{ }^{* * H i g h l y ~ s i g n i f i c a n t ~}(P \leq 0.001)$

Table 2: Changes in serum biochemistry of castrated male albino rats after the treatment of Testosterone Propionate and Cassia tora

\begin{tabular}{|c|c|c|c|c|c|}
\hline Treatment & $\begin{array}{c}\text { Acid } \\
\text { phosphatase } \\
\text { (IU/L) }\end{array}$ & $\begin{array}{c}\text { Alkaline } \\
\text { phosphatase } \\
\text { (IU/L) }\end{array}$ & $\begin{array}{l}\text { LDH } \\
\text { (U/L) }\end{array}$ & $\begin{array}{l}\text { SGOT } \\
\text { (IU/L) }\end{array}$ & $\begin{array}{l}\text { SGPT } \\
\text { (IU/L) }\end{array}$ \\
\hline $\begin{array}{c}\text { Group A } \\
\text { Control }\end{array}$ & $2.19 \pm 0.20$ & $87.22 \pm 9.62$ & $140.53 \pm 18.39$ & $19.76 \pm 0.63$ & $28.88 \pm 0.70$ \\
\hline $\begin{array}{c}\text { Group B } \\
\text { Castration }\end{array}$ & $2.70 \pm 0.11^{*}$ & $111.79 \pm 4.70 *$ & $129.74 \pm 6.62^{n s}$ & $22.47 \pm 1.50^{\mathrm{ns}}$ & $26.20 \pm 1.47^{\mathrm{ns}}$ \\
\hline $\begin{array}{c}\text { Group C } \\
\text { Castration+ } \\
\text { Cassia tora } 100 \\
\text { mg/kg.b.wt. }\end{array}$ & $2.46 \pm 0.13^{n s}$ & $110.70 \pm 3.06^{\mathrm{ns}}$ & $126.29 \pm 8.09^{n s}$ & $24.39 \pm 1.67^{\mathrm{ns}}$ & $24.42 \pm 1.65^{\mathrm{ns}}$ \\
\hline $\begin{array}{c}\text { Group D } \\
\text { Castration + } \\
\text { Testosterone } \\
\text { Propionate }\end{array}$ & $3.01 \pm 0.07^{*}$ & $124.03 \pm 2.19 *$ & $125.69 \pm 7.76^{\mathrm{ns}}$ & $23.55 \pm 1.57^{\mathrm{ns}}$ & $24.39 \pm 1.42^{\mathrm{ns}}$ \\
\hline
\end{tabular}




\section{Group E}

Castration +

Testosterone $\quad 3.00 \pm 0.07^{*} \quad 123.22 \pm 1.90^{*} \quad 136.23 \pm 6.82^{\mathrm{ns}} \quad 24.69 \pm 1.67^{\mathrm{ns}}$
Propionate+
Cassia tora
$100 \mathrm{mg} /$ kg.b.wt.

Data exposed as Mean $\pm S . E, n s=$ non-significant, ${ }^{*}$ Significant $(\mathrm{P} \leq 0.01),{ }^{* *}$ Highly significant $(\mathrm{P} \leq 0.001)$

Table 3: Changes in protein, sialic acid and fructose contents after the treatment of Testosterone Propionate and Cassia tora in castrated male albino rats

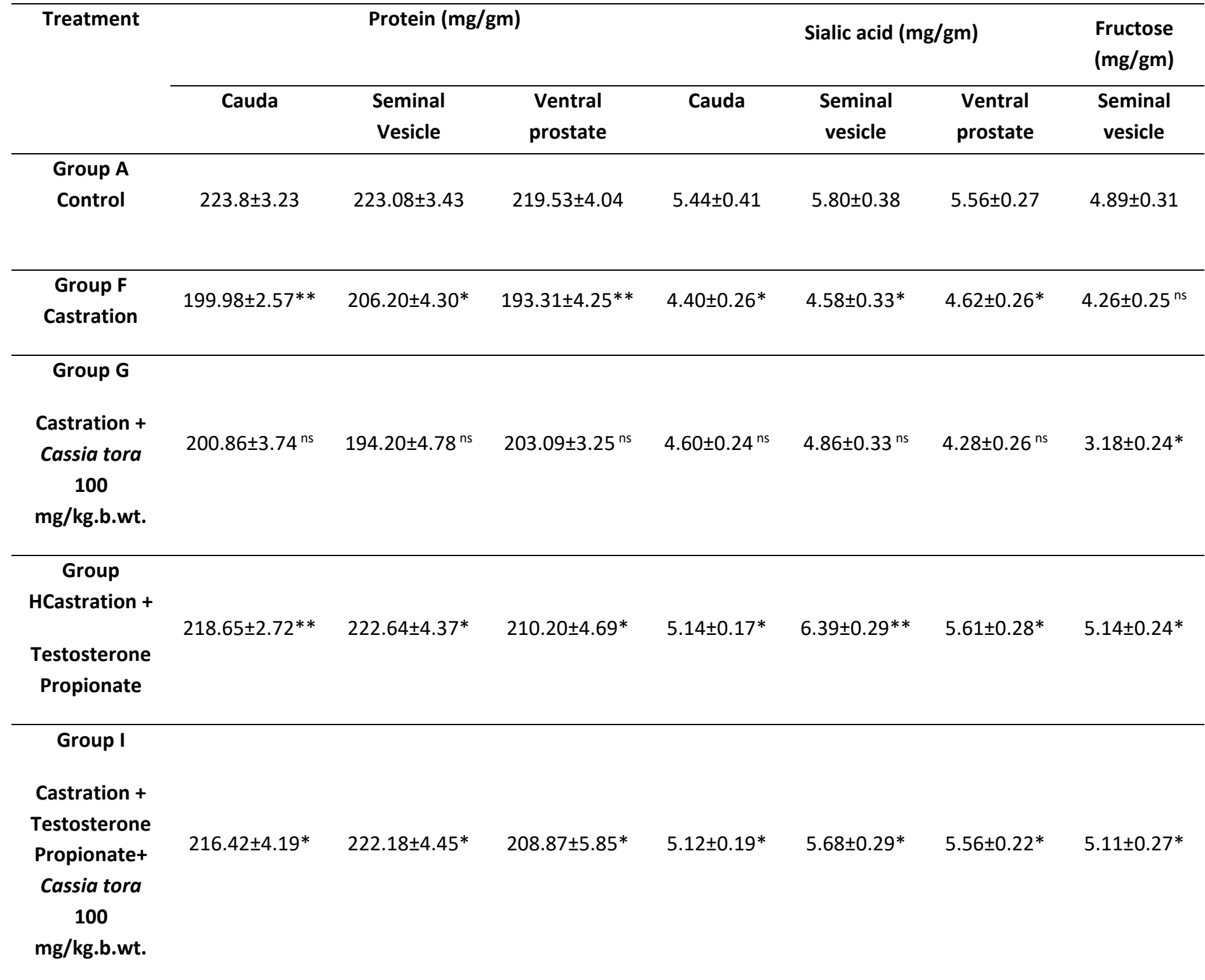

Data exposed as Mean $\pm S . E, n s=$ non-significant, ${ }^{*}$ Significant $(\mathrm{P} \leq 0.01),{ }^{* *}$ Highly significant $(\mathrm{P} \leq 0.001)$ 
SSR Inst. Int. J. Life Sci.

Khan and Mali, 2019

crossef DOI:10.21276/SSR-IIJLS.2019.5.2.8
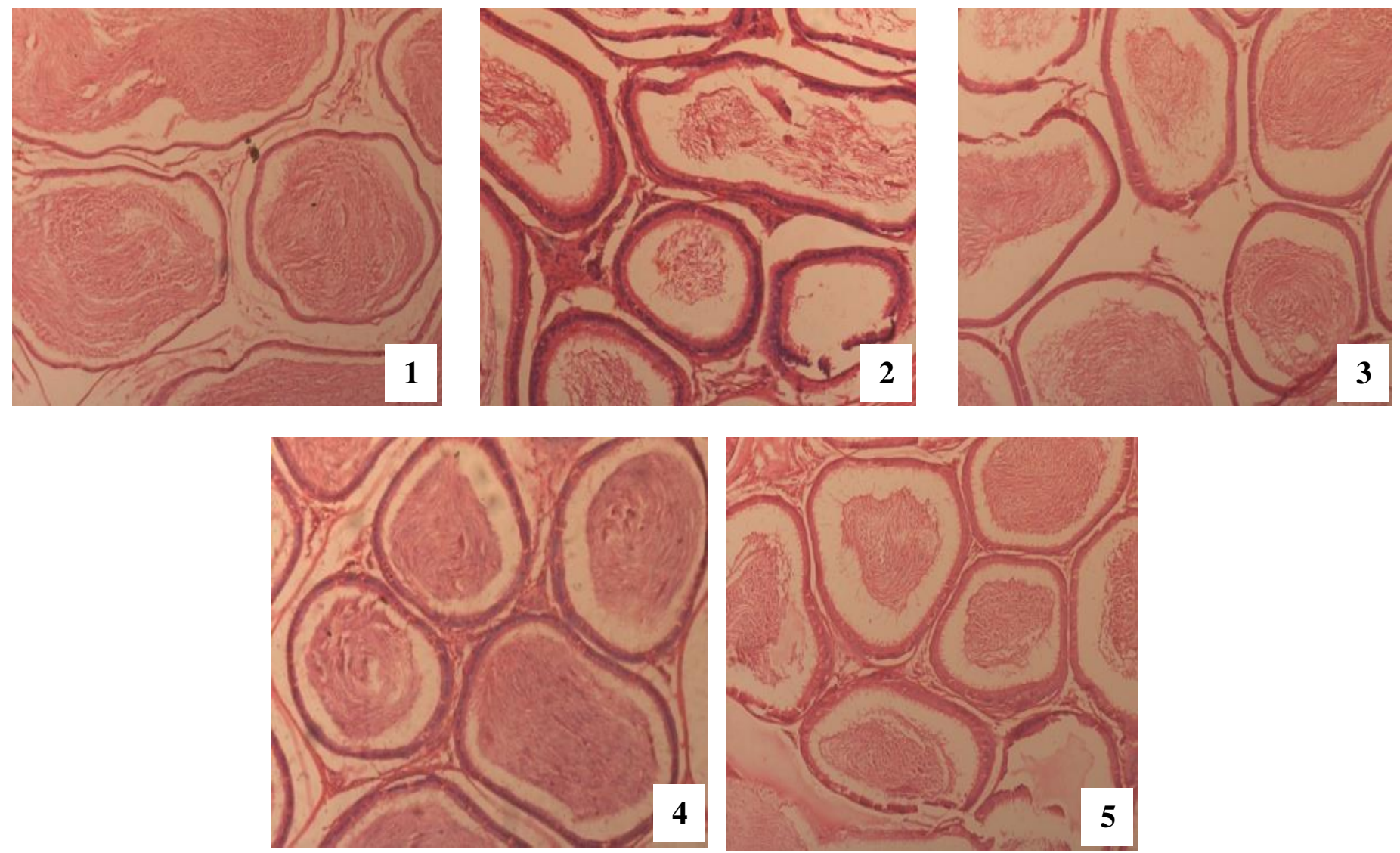

Fig. 1: Photomicrograph of changes in histoarchitecture of cauda epididymis (1-5) from Group A-E
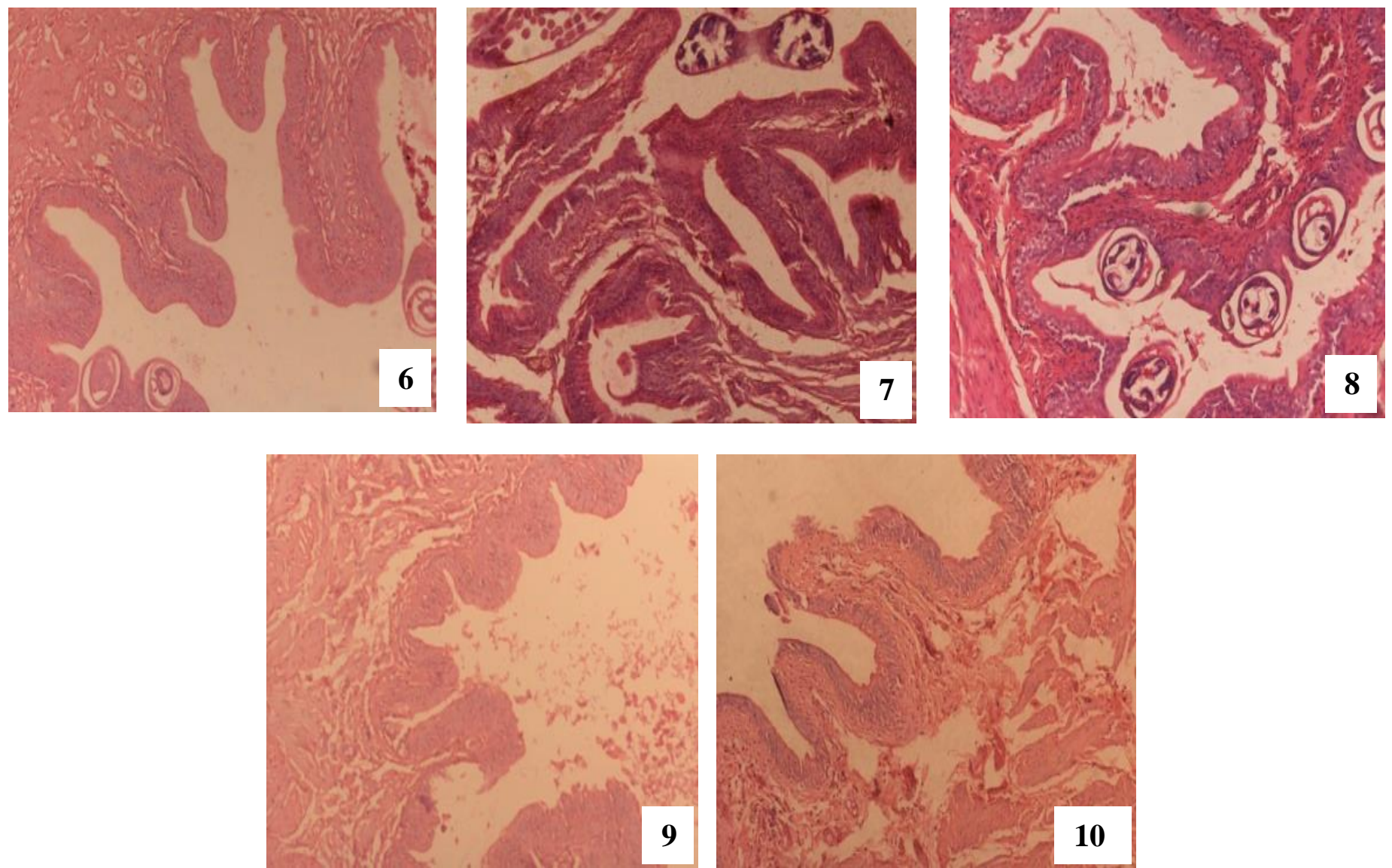

Fig. 2: Photomicrograph of changes in histoarchitecture of seminal vesicle (6-10) from Group A-E 


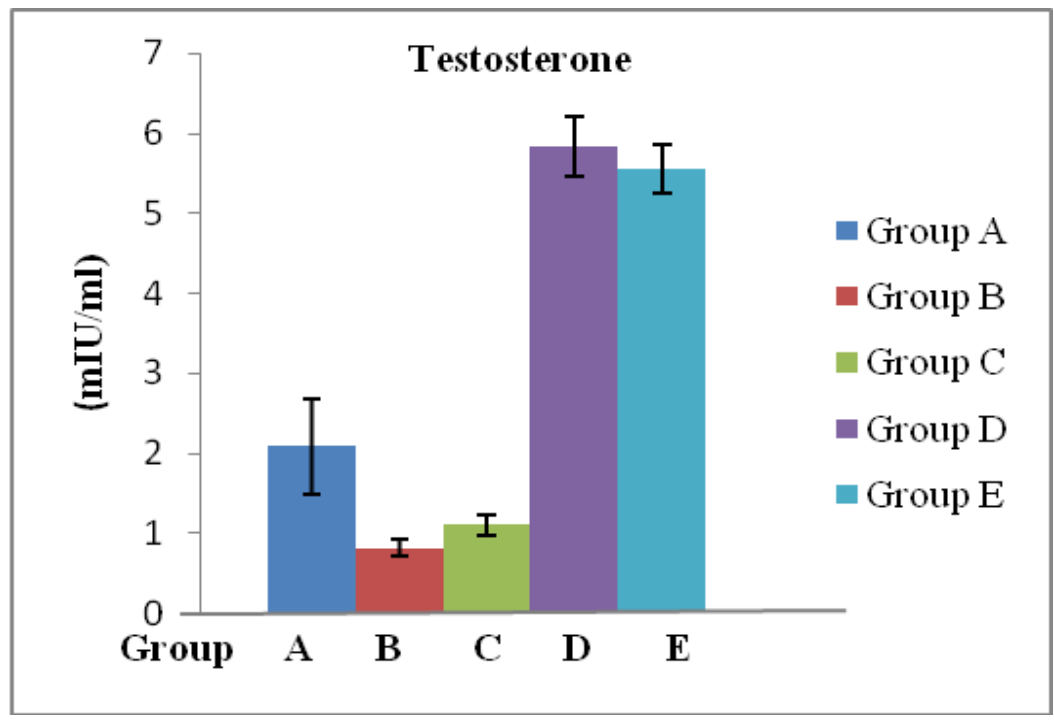

Fig. 3: Effect of Cassia tora treatment on testosterone level of castrated rats

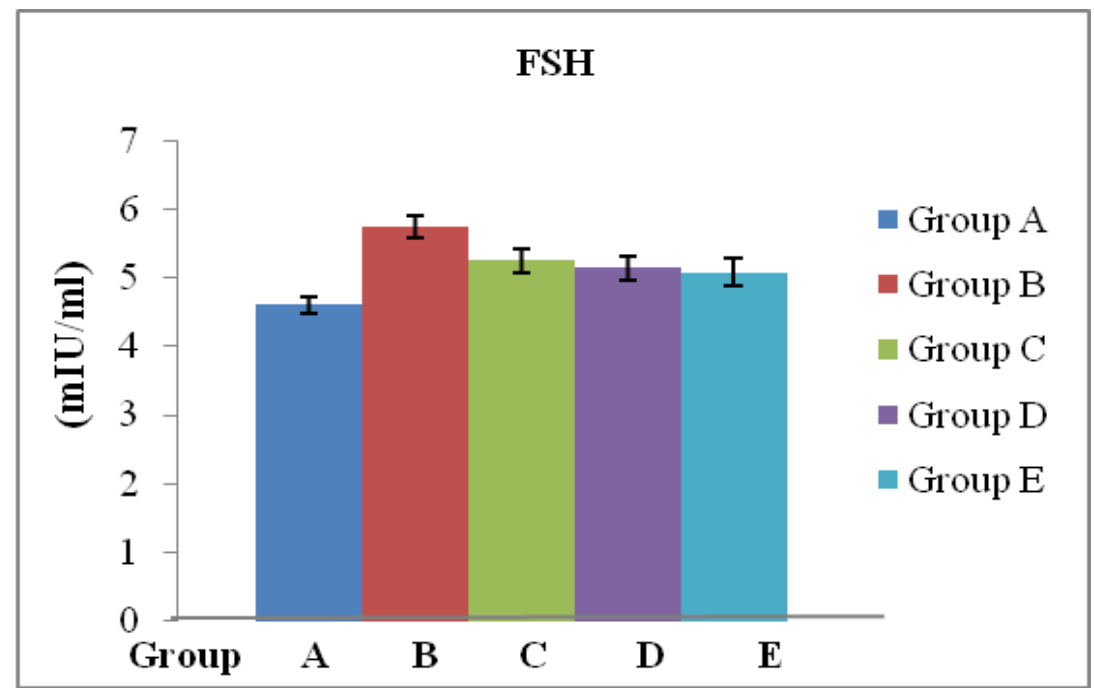

Fig. 4: Effect of Cassia tora treatment on FSH level of castrated rats

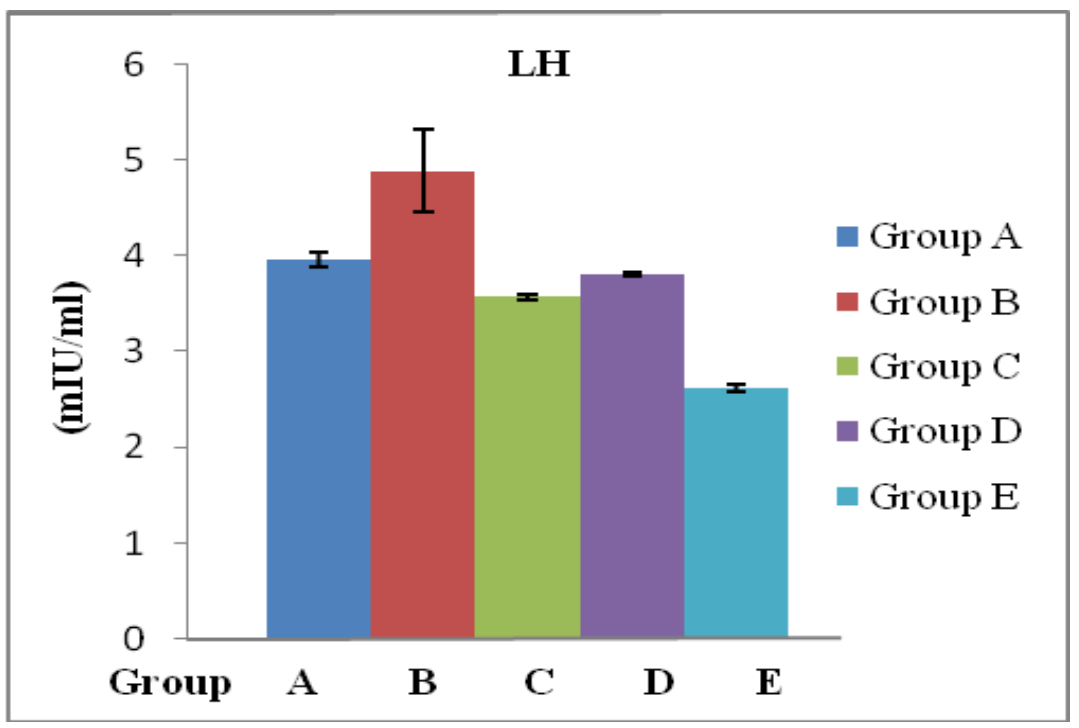

Fig. 5: Effect of Cassia tora treatment on LH level of castrated rats 


\section{DISCUSSION}

The $50 \%$ ethanolic extract of the plant Cassia tora treatment affect the physiological functions of castrated male reproductive organs, reflected in reduced weight of accessory organs, protein, sialic acid, fructose, and testosterone, FSH and $\mathrm{LH}$ hormones levels. In castrated treated rats resulted in degenerative changes in the structural and functional integrity of these organs had been assessed by the estimation of biochemical parameters of serum and tissues and histoarchitecture. It has been reported that androgens were essential for the growth and development of reproductive functions and the suppression of gonadotropins, might inhibit spermatogenesis ${ }^{[22,23]}$. Gonadotrophins and testosterone were the leading regulators of germ cell development ${ }^{[24]}$. FSH, LH and testosterone hormones were required for initiation as well as maintenance of spermatogenesis process. FSH acts as a mitogen for postnatal sertoli cell proliferation in rat ${ }^{[22,25,26]}$. LH through specific receptors was found on the surface of leydig cells, control the production and secretion of testosterone ${ }^{[27]}$. The treatment of Cassia tora extracts alone in castrating for also worth very low levels of androgen. Therefore, the androgenic stimulation in castrate treated rats which show administration of TP stimulates the androgen secretion. While continued declined androgen level caused degenerative changes in reproductive organs $[28,29]$. The extract treatment in castrated rats significantly decreased the epididymis weight, might be due to the reduced level of testosterone or androgens. Monitoring body weight provides information on the general health level of animals, which can be important to the interpretation of reproductive effects. After castration, the size of epididymis was regressed morphologically leads to changes in absorptive and secretory activity ${ }^{[30]}$. Synthesis of the proteins in the accessory sex organs are androgen dependent. Administration of Cassia tora extract in castrated rats caused anti-androgenic effect to reflect a significant decreased of the proteins in epididymis, which was restored to normal levels after testosterone therapy. Results of the castrated rats treated with Cassia tora extracts along with TP reveals an increased in protein and sialic acid contents due to testosterone substitution ${ }^{[28,31]}$. The fructose serves as a source of energy for sperm maturation and can be measured with the secretory activity of seminal vesicle $[32,33]$. It can be suggested that the depletion of fructose content in reproductive tract decreased after treatment of extract possibly due to anti-androgenic nature of drug [34,35]. The epithelium of epididymis secretes proteins within the intra-luminal compartment that created an environment surrounding the spermatozoa [36]. Castration of rats caused reduction in tubular size, degeneration of germinal epithelium, disappearance of stereocilia, in inter-tubular stroma in epididymis with the extract treated rats. Thus, the photomicrograph of epididymis showed degenerative changes in the structure of epididymis after castrations were due to decrease secretion. Tindall et al. ${ }^{[37]}$ suggested that castration of rats resulted in the reduction of tubular diameter and loss cellular components require for growth and development of epididymis due to the reduced level of circulating androgens.

\section{CONCLUSIONS}

It can be concluded that the anti-androgenic nature of the drug Cassia tora extract, administration to the castrated rats in combination with TP increased the epididymis weight, but it could not reach up to the level of TP treated castrates because Cassia tora suppressed the action of TP. However, these changes in histological features cannot be compared with TP treated castrated groups. It was assumed that medicinal plant Cassia tora has a potentially reversible contraceptive activity therefore it would be a good systematic anti-fertility drug.

Potential use will to a degree be influenced by the mode of action of the drug. The future acceptability of the use of medicinal plant will be closely linked to herbal contraception.

\section{ACKNOWLEDGMENTS}

Authors were thankful to the Head and Coordinator, Centre for Advanced Studies, Department of Zoology, University of Rajasthan, Jaipur for laboratory facilities and UGC, New Delhi for partial financial support.

\section{CONTRIBUTION OF AUTHORS}

Research concept- Dr. PC Mali

Research design- Dr. PC Mali

Supervision- Dr. PC Mali

Materials- Dr. Samiya khan

Data collection- Dr. Samiya khan

Data analysis and interpretation- Dr. PC Mali, Dr. Samiya khan

Literature search- Dr. PC Mali, Dr. Samiya khan 
Writing article- Dr. Samiya khan

Critical review- Dr. Samiya khan

Article editing- Dr. PC Mali

Final approval- Dr. PC Mali

\section{REFERENCES}

[1] Black AY, Fleming NA, Rome ES. Pregnancy in adolescents. Adolesc. Med. State Art. Rev., 2012; 23(1): 123-38.

[2] Ahmed S, Li Q, Liu L, Tsui AO. Maternal deaths averted by contraceptive use an analysis of 172 countries. Lancet, 2012; 380(9837): 111-25.

[3] Naiho AO, Chris-ozoko LE, Aloamaka CP. The impact of crude oil on reproduction in wistar rats. J. Pharm. Bio. Sci., 2014; 9(3): 01-05.

[4] WHO. Reproductive health research at WHO, a new beginning, Biennial Report 1998-99 Special programme of research development and research training in human reproduction, World Health Organisation, Geneva, 2000.

[5] Shrivastava AK. Medicinal and herbal species, medicinal plants, APH Publishing corporation New Delhi, 2006; 121: 52-53.

[6] Wong SM, Wong MM, Seligmann O, Wagner H. New antihepatotoxic naphtha-pyrone glycosides from the seeds of Cassia tora. Planta. Med., 1989b; 55: 276-80.

[7] Zhang Z, Yu B. Total synthesis of the antiallergic naphtha- $\alpha$-pyrone tetraglucoside, cassiaside $\mathrm{C} 2$, isolated from Cassia seeds. J. Org. Chem., 2003; 68: 6309-13.

[8] Kim YM, Lee $\mathrm{CH}$, Kim HG, Lee HS. Anthraquinones isolated from Cassia tora (Leguminosae) seed show an antifungal property against phytopathogenic fungi. J. Agric. food Chem., 2004; 52: 6096-7000.

[9] Maity TK, Dinda SC. Purgative activity of Cassia tora leaf extract and isolated aloe-emodin. Int. J. Pharmaceu. Sci., 2003; 65(1): 93-95.

[10]Patil UK, Saraf S, Dixit VK. Hypolipidemic activity of seeds of Cassia tora (Linn.). J. Ethnoparmacol., 2004; 90: 249-52.

[11]Khan S, Mali PC. Reversible antifertility effect of Cassia tora Linn in male rats. Int. J. Life Sci. Scienti. Res., 2017; 3(5): 1415-23.

[12]Mali PC. Phytomedicine can provide a safe and reversible male contraceptive. Planta Med., 2009; 75: 1005-06.
[13]El-Halawany AM, Chung MH, Nakamura N, Ma CM, Nishihara T, Hattori $M$. Estrogenic and antiestrogenic activities of Cassia tora phenolic constituents. Chem. Pharm. Bull., 2007; 55(10): 1476-82.

[14]Hatano T, Mizuta S, Ito H, Yoshida T. C-glcosidic flavonoids from Cassia tora. Pytochem., 1999; 52(7): 1379-83.

[15]WHO. Protocol CG-04 Preparation of alcoholic extract for bioassay and phytochemical studies (APJF/IP, 100 1A) Geneva, WHO, 1983.

[16]Lowry OH, Rosenbrough NJ, Far AL, Randall RJ. Protein measurements with the folin phenol reagents. J. Biol. Chem., 1951; 193: 265-75.

[17]Warren L. The thiobarbituric acid assay of sialic acid. J. Bio. Chem., 1959; 234: 1971-75.

[18]Foreman D. A modification of the Roe procedure for determination of Fructose in tissues with specificity. Analyt. Biochem., 1973; 56: 584-90.

[19]WHO. Annual technical report, 1998 Special programme of research development and research training in human reproduction, World Health Organisation, Geneva, 1999.

[20]Gupta S. Sampling and test of significance In: Gupta S (eds.) Statistical Methods. Sultan chand and sons Publishers, New Delhi, 1978; pp. 58-76.

[21]CPCSEA. Committee for the purpose of control and supervision on experiments on animals. ICMR, New Delhi, 2006.

[22] O'Shaughnessy PJ, Morris ID, Huhtaniemi I, Baker PJ, Abel $\mathrm{MH}$. Role of androgen and gonadotrophins in the development and function of the sertoli cells and leydig cells: data from mutant and genetically modified mice. Mol. Cell. Endocrinol., 2009; 306: 0208.

[23] O’Donnell L, McLachlan RI. The role of testosterone in spermatogenesis. In: Testosterone: action, deficiency, substitution, eds. Nieschlag E, Behre HM, Nieschlag S Cambridge University Press, New York, USA, $4^{\text {th }}$ ed, 2012: 123-53.

[24]Ruwanpura SM, McLachlan RI, Meachem SJ. Hormonal regulation of male germ cell development. J. Endocrinol., 2010; 205: 117-131.

[25]Donnell LO, De KDM. Endocrinology of the male reproductive system. Endotext., 2013; pp. 20-57. 
[26]Kamischke A, Nieschlag E. Progress towards hormonal male contraception. Trends Pharmacol. Sci., 2004; 25(1): 49-57.

[27]Oyeyemi MO. Changes in sperm characteristics and testis and epididymis of experimental rats by an herbicide, atrazine. Arch. Environ. Contamin. toxicol., 2009; 58(3): 874-82.

[28]Rajalakshmi M, Prasad MRN. Regional differences in androgen thresholds of the epididymis of the castrated rat. Steroids, 1974; 24(4): 575-86.

[29]Podesta EJ, Calandra RS, Rivarola MA, Blaquier JA. The effect of castration and testosterone replacement on specific proteins and androgen levels of the rat epididymis. Endocrinol., 1975; 97 : 399-405.

[30]Kyprianou N, Isaacs JT. Biological significance of measurable androgen levels in the rat ventral prostate following castration. Prostate, 1987; 10(4): 313-24.

[31]Annamalai JK, Irisappan SC. Male antifertility activity of hydro-alcoholic stem and leaf extracts of Ecballium Elaterium on male wistar rats. Int. J. Med. Pharm. Res., 2018; 6(6): 253-55.

[32] Lu JC, Chen F, Xu HR, Huang YF, Lu NQ. Standardization and quality control for determination of fructose in seminal plasma. J. Androl., 2007; 28: 207-13.
[33]Mali PC, Ansari AS, Chaturvedi M. Antifertility effect of chronically administered Martynia annua root extract on male rats. J. Ethnopharmacol., 2002; 82 (2-3): 61-67.

[34]Rahman RFA, Ankaya ITA, Alqasoumi SI, Yusufoglu H, Anul SA, Akaydin G, Soliman GA. Evaluating the antifertility potential of the ethanolic extracts of Bupleurum sulphureum and Cichorium intybus in male rats. Asn. J. Pharm. Clin. Res., 2014; 7(1): 211-18.

[35] Singh A, Singh SK. Reversible antifertility effect of aqueous leaf extract of Allamanda cathartica (Linn.) in male laboratory mice. Andrologia., 2008; 40(6): 337-45.

[36]Soni PK, Mali PC. Oral administration of petroleum ether extract of Tecomella undulata leaves affects spermatogenesis and fertility of male rats. Europ. J. Biomed. Pharmaceut. Sci., 2016; 3: 339-44.

[37]Tindall DJ, Hansson V, Sar M, Stumpf WE, French FS and Nayfeh SN. Further studies on the accumulation and binding of androgen in rat epididymis. Endocrinol., 1974; 95: 1119-28.

\section{Open Access Policy:}

Authors/Contributors are responsible for originality, contents, correct references, and ethical issues. SSR-IIJLS publishes all articles under Creative Commons Attribution- Non-Commercial 4.0 International License (CC BY-NC). https://creativecommons.org/licenses/by-nc/4.0/legalcode (c) (1) (9) 